\title{
TRIASSIC CARBONATE AND EVAPORITE SEDIMENTATION IN THE IONIAN ZONE (WESTERN GREECE): PALAEOGEOGRAPHIC AND PALAEOCLIMATIC IMPLICATION
}

\author{
Getsos K. ${ }^{1}$, Pomoni-Papaioannou F. ${ }^{2}$ and Zelilidis A. ${ }^{1}$ \\ ${ }^{1}$ Laboratory of Sedimentology, School of Geology, University of Patras, 26500 Patras, \\ K.Getsos@upatras.gr, A.Zelilidis@upatras.gr
}

${ }^{2}$ Department of Geology, University of Athens, Panepistimiopolis, 15784 Athens, fpomoni@geol.uoa.gr

\begin{abstract}
The Triassic is considered a crucial interval because during that time huge areas in our planet suffered an intense, long lasting, period of aridity, which favored the formation of worldwide evaporitic bodies. During the Triassic, great volumes of evaporites were formed in the lonian basin (Western Greece). On the surface chaotically textured gypsum, surrounded by dolomitic breccias of solution-collapse origin, appears. Sedimentological and diagenetical data proposed that these salt bodies were formed in an intertidal to supratidal environment.

Although halite suggests precipitation under long-term arid conditions, clay film intercalations reveal intervals of short term humid conditions. During arid periods sabkhas prevailed and brines were of marine origin. Instead, during humid intervals brines were modified by meteoric water and stormy episodes could be responsible for the transportation of clay-sized material, from the low relief surrounding terrains, into the evaporative basin. Death and burial of cyanobacterial population during storm events could be responsible for the enrichment of clayey layers in carbonaceous material.
\end{abstract}

The co-existence of halite and clays in the Ionian evaporitic sequence imposes a complicated climate, possibly periodically and seasonally controlled. The impact of the precession of the equinoxes plus the palaeogeographical position dominates the local climate. The insolation over the Triassic Ionian basin and nearby sea and land areas is a crucial factor. Climate responses to gradual insolation forcing with an ocean land atmosphere feedback mechanism. The desert / monsoonal dominated climatic model seems to be most proper for the explanation of the existing lithologigal record.

\section{INTRODUCTION}

In the geologic record massive evaporative deposits occur predominantly in subtropical coastal regions where annual evaporation exceeds precipitation. Evaporites are indicative of hot-dry climates and organic layers, algal mats, are indicative of humid climates. In the case of the evaporites there is much difference in the climatic conditions, between gypsum and halite which is indicative of extremely arid climates.

During Triassic several evaporative basins occurred in the Tethyan realm. In the early Triassic large fine clastic-evaporitic basins were located in the northern part of the Permian Basin, in westcentral Europe, in part or Eastern Europe and in the Arabian Platform. In middle Triassic there were two large evaporitic basins; one is located in Iraq and the other in southwest-central Europe. Most of Tethys was intertropical or subtropical. During late Triassic large evaporitic basins were located in south and west-central Europe. Widely known from this time interval is the "Germanic Basin" and the "Carpathian Keuper". Tethys was in an intertropical paleoposition.

The variations in insolation result from the tilt of the earth's axis relative to the plane of the earth's orbit. The intensity of the seasonal insolation varies on $10^{4}-10^{5}$-year timescale because of 
the earth's orbital parameters. The major parameters affecting insolation are: (a) the ellipticity of the earth's orbit, which changes the distance from earth to the sun during the course of the year and varies on a 95000-year timescale, with a longer cycle of variation at a 400000 -year timescale; (b) the tilt of the earth's axis of rotation relative to the plane in which it orbits the sun (ecliptic), which varies between $22^{\circ} 2^{\prime}$ and $24^{\circ} 30^{\prime}$ on a 41000 -year timescale; (c) the precession of the elliptical orbit of the earth, which changes the time of the year when the planet is closest to the sun and has a period of approximately 105000 years; and (d) the precession of the earth's axis of rotation, which changes the season at which the earth is closest to the sun and has a period of 27000 years. The combined effect of precession of the axis of rotation and the elliptical orbit is to produce an apparent period of 23000 years. Similarly, the cyclic changes in ellipticity and precession of the axis of rotation combine to produce an apparent period of 19000 years. The two apparent periods, 23000 and 19000 years, blend together so that perihelion coincides with seasonal summer in each hemisphere approximately every 21700 years. This combined effect is termed the precession of the equinoxes. It redistributes the amount of insolation received at different latitudes during seasons (Berger 1977, 1981, 1984, 1987a; Imbrie \& Imbrie 1980; Hay et al. 1997).

The target of the paper is to study the sedimentological and diagenetical features of Triassic rocks (Fig. 1) and set up the climatic conditions during Triassic. The desert/monsoon climatic model is examined as well a model with impact of El-Niño events. Two similar studies, one from Late Miocene palaeogeography and palaeoclimatology of the Mediterranean basin and one from Christmas islands lagoonal lakes are presented briefly.

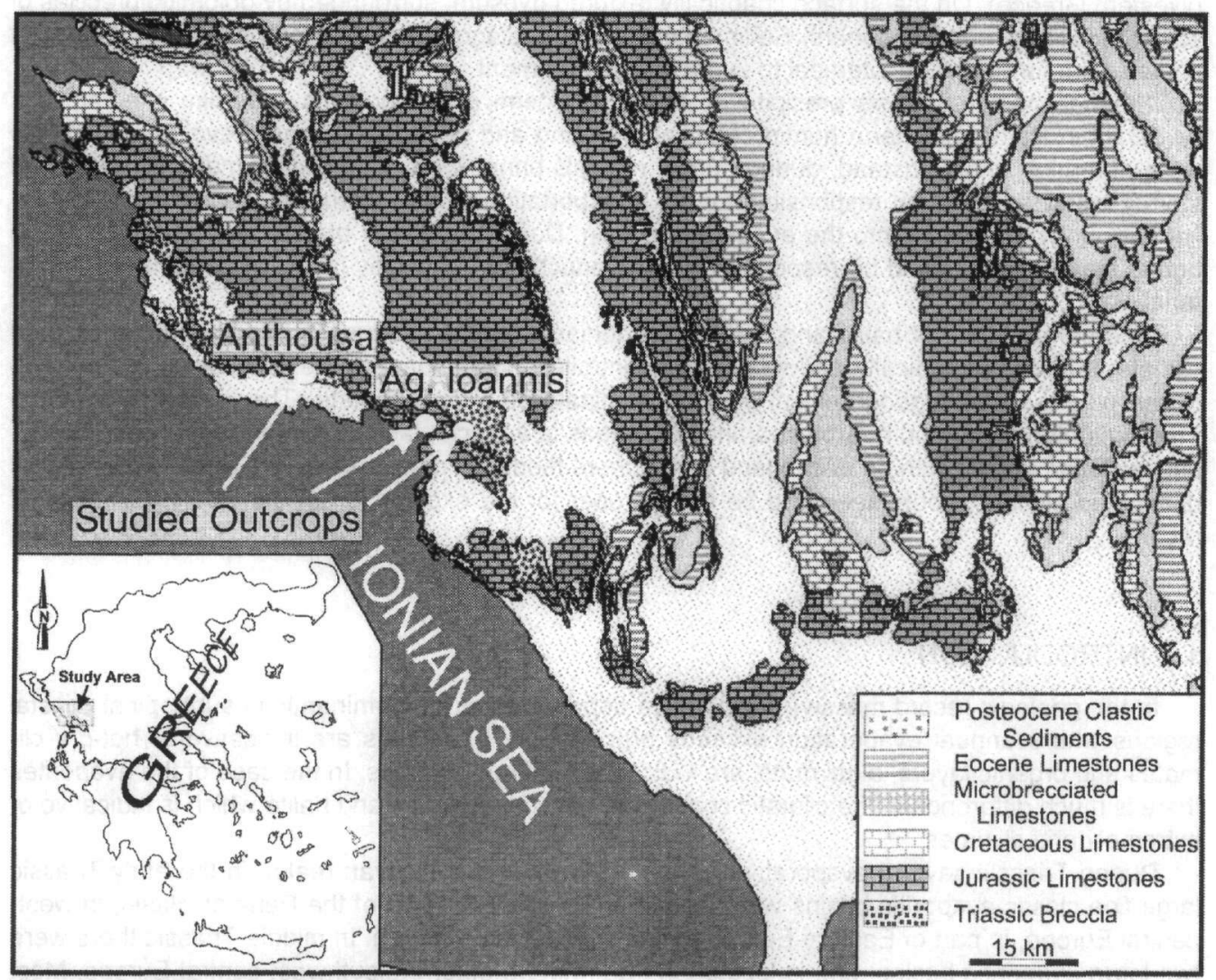

Figure 1. Geologic map of the studied area.

Sampling was performed in the areas of Agios loannis $(4,353,504.32 \mathrm{~N}, 196,284.60 \mathrm{E}$ \& $4,353,612.57 \mathrm{~N}, 198,557.75 \mathrm{E})$ and Anthousa $(4,356,318.69 \mathrm{~N}, 188,707.45 \mathrm{E})$ near Parga, in Western Greece (Fig. 1). The studied formations are exposed in a chaotic mass of fragments bearing 
diagenetic and post tectonic dissolution vugs (Fig. 2A, B). A large part consists of breccias, with solution collapse in origin. One hundred and five samples were collected with about one meter sampling interval. Ninety three thin sections were studied in every detail under polar microscopy. Fifty seven samples were stained with alizarin red $\mathrm{S}$ in order to distinguish dolomite from calcite.

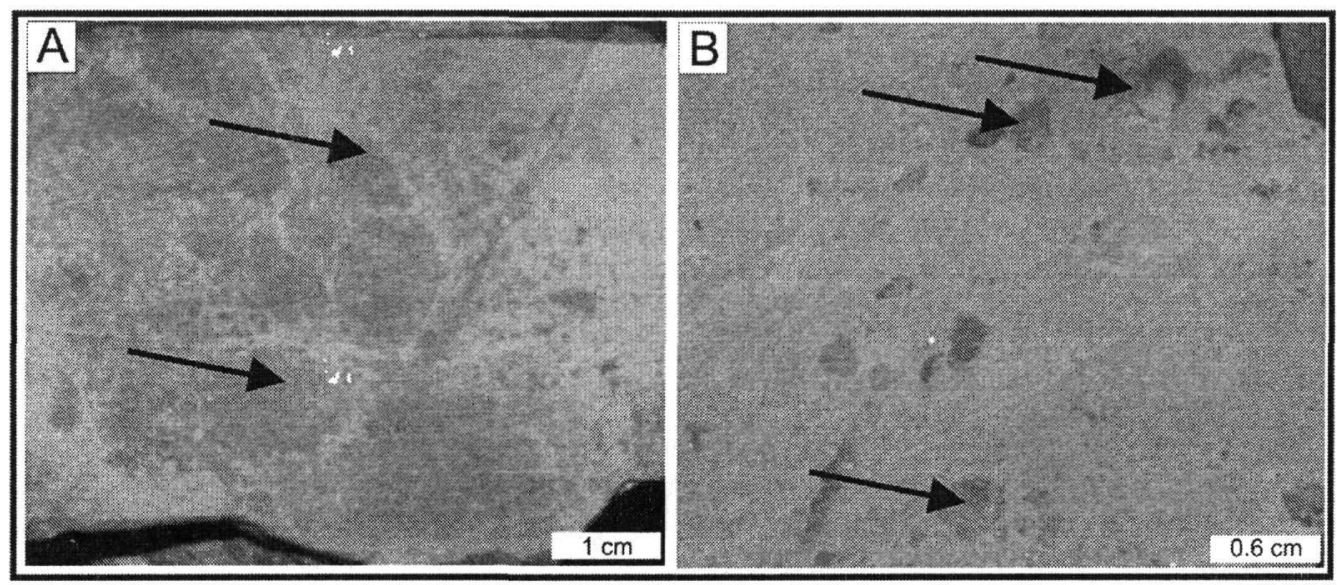

Figure 2. (A) Cemented fragments, (B) Diagenetic and post tectonic dissolution vugs.

\section{GEOLOGICAL SETTING}

The Ionian Basin developed during the Mesozoic as a branch of Tethys. The rifting of Africa from North Europe in Triassic times gave rise to terrigenous basins and subsequent development of evaporites in wide areas of shallow water deposition (Catalano et al. 2001).

The Ionian zone exhibits a sedimentary cover, $4.5-5 \mathrm{~km}$ thick, from Triassic to present. The dense overlying Mesozoic limestones prevented diapirism in the Ionian zone. Usually salt bodies are dragged up through discontinuities, such as normal faults and thrusts which cut the overlying sedimentary cover. The only known structure which bears great similarity to diapiric bodies exists in Albania. Research has revealed its pseudodiapiric origin (Velaj et al. 1999). The subsurface lithology of the carbonate - evaporite sequence consists of millimetre to centimetre scale intercalations of halite, anhydrite, dolomites and clays (IGRS-IFP, 1966; BP, 1971).

\section{SEDIMENTOLOGY}

\subsection{Description}

The lithofacies consist mainly of dolomite, rare anhydrite/gypsum and calcite (dedolomite) (Tab. 1). The main Standard Lithofacies Types (SMF) after Flugel (1972) and Wilson (1975) are SMF 23 and SMF 24. The main sharacteristics of type 23 are gypsum, anhydrite and dolomite irregularly laminated and type 24 is dolomite and dolomitic limestones with evaporitic crystals. The two types are similar and their initial characteristics are strongly modified by early diagenetical processes. Dolomite fragments bear carbonate pseudomorphs after rosettes and lenses of gypsum (Fig $3 A$, $3 \mathrm{~B}$ ). Rosettes are characterized by a radiaxial or fibrous structure. Moreover radiaxial cement is usual in the studied samples (Fig. $3 \mathrm{C}$ ). Dolomite crystals are euhedral and form a mosaic of rhombs with moulds of original dense calcite particles (Fig. 3D). The mosaic is often loose-fitting (Fig. 3E, $3 F$ ). In many thin sections several early diagenetic desiccation cracks have been studied within recrystalized lime mudstone (Fig. 3G). Usually the fragments were cemented with red brown cement typical of subaerial diagenesis (Fig. $3 \mathrm{H}$ ). Similar features have been described and interpreted by Pomoni-Papaioannou (1980) and Karakitsios \& Pomoni-Papaioannou (1998).

In core samples halite is present with intercalations of clayey beds, which contain very fine carbonaceous material. The death and burial of cyanobacterial population during extreme events is the 
possible source of this material.

The complete absence of fragmented older, Paleozoic, and newer, Jurassic, rocks from the studied chaotically textured breccias must be mentioned.

Table 1. Representative microscopic and macroscopic description. Standard Microfacies Types (SMF) and Facies Zone (FZ) after Flugel (1972) and Wilson (1975). N. =Sample number.

\begin{tabular}{|c|c|c|c|c|}
\hline N. & Microscopic Description & SMF & $\overline{F Z}$ & $\begin{array}{l}\text { Macroscopic } \\
\text { Description }\end{array}$ \\
\hline 1 & $\begin{array}{l}\text { Solution Collapse Breccias, dolo- } \\
\text { mitized mudstone, dolomite } 55 \% \text {, } \\
\text { micritic matrix or cement } 30 \% \text {, } \\
\text { secondary porosity } 15 \% \text {. }\end{array}$ & $\begin{array}{l}\text { 24: Dolomite and Dolo- } \\
\text { mitic limestones with } \\
\text { evaporitic crystals. }\end{array}$ & $\begin{array}{l}\text { 8: Restricted cir- } \\
\text { culation shelf } \\
\text { and tidal flats. }\end{array}$ & $\begin{array}{l}\text { Vugy and } \\
\text { fragmented }\end{array}$ \\
\hline 2 & $\begin{array}{l}\text { Solution Collapse Breccias, } \\
\text { evaporitic rosette and lenses } \\
\text { within mudstone, secondary poros- } \\
\text { ity } 25-30 \% \text {. }\end{array}$ & $\begin{array}{l}\text { 23: Gypsum, anhydrite } \\
\text { and dolomite irregularly } \\
\text { laminated. }\end{array}$ & $\begin{array}{l}\text { 9: Evaporites on } \\
\text { sabkhas } \\
\text { Salinas. }\end{array}$ & $\begin{array}{l}\text { Vugy and } \\
\text { fragmented }\end{array}$ \\
\hline 3 & $\begin{array}{l}\text { Solution Collapse Breccias, Grain- } \\
\text { stone, secondary porosity } 25-30 \% \text {. }\end{array}$ & $\begin{array}{l}\text { 24: Dolomite and Dolo- } \\
\text { mitic limestones with } \\
\text { evaporitic crystals. }\end{array}$ & $\begin{array}{l}\text { 8: Restricted cir- } \\
\text { culation shelf } \\
\text { and tidal flats. }\end{array}$ & $\begin{array}{l}\text { Vugy and } \\
\text { fragmented }\end{array}$ \\
\hline 4 & $\begin{array}{l}\text { Solution Collapse Breccias, red } \\
\text { brown micritic cement, calcified } \\
\text { and dolomitized gypsum/anhydrite } \\
\text { with open dissolution vugs. Micrite } \\
10 \% \text {, dolomite } 35 \% \text {, evaporite } \\
20 \% \text {, secondary porosity } 35 \% \text {. }\end{array}$ & $\begin{array}{l}\text { 24: Dolomite and Dolo- } \\
\text { mitic limestones with } \\
\text { evaporitic crystals. }\end{array}$ & $\begin{array}{l}\text { 8: Restricted cir- } \\
\text { culation shelf } \\
\text { and tidal flats. }\end{array}$ & $\begin{array}{l}\text { Vugy and } \\
\text { fragmented }\end{array}$ \\
\hline 5 & $\begin{array}{l}\text { Solution Collapse Breccias, many } \\
\text { fragments cemented with sparite, } \\
\text { secondary porosity } 35-40 \% \text {. }\end{array}$ & $\begin{array}{l}\text { 24: Dolomite and Dolo- } \\
\text { mitic limestones with } \\
\text { evaporitic crystals. }\end{array}$ & $\begin{array}{l}\text { 8: Restricted cir- } \\
\text { culation shelf } \\
\text { and tidal flats. }\end{array}$ & $\begin{array}{l}\text { Vugy and } \\
\text { fragmented }\end{array}$ \\
\hline 6 & $\begin{array}{l}\text { Solution Collapse Breccias, dolo- } \\
\text { mite with relic sparite crystals and } \\
\text { relic evaporites, dolomite } 60 \% \text {, } \\
\text { secondary porosity } 30 \% \text {, relics } \\
10 \% \text {. }\end{array}$ & $\begin{array}{l}\text { 23: Gypsum, anhydrite } \\
\text { and dolomite irregularly } \\
\text { laminated. }\end{array}$ & $\begin{array}{l}\text { 9: Evaporites on } \\
\text { sabkhas } \\
\text { Salinas. }\end{array}$ & $\begin{array}{l}\text { Vugy and } \\
\text { fragmented }\end{array}$ \\
\hline 7 & $\begin{array}{l}\text { Solution Collapse Breccias, dolo- } \\
\text { mite (Grainstone), red brown } \\
\text { sparitic cement, secondary poros- } \\
\text { ity } 20 \% \text {, dolomite } 80 \% \text {. }\end{array}$ & $\begin{array}{l}\text { 24: Dolomite and Dolo- } \\
\text { mitic limestones with } \\
\text { evaporitic crystals. }\end{array}$ & $\begin{array}{l}\text { 8: Restricted cir- } \\
\text { culation shelf } \\
\text { and tidal flats. }\end{array}$ & $\begin{array}{l}\text { Vugy and } \\
\text { fragmented }\end{array}$ \\
\hline 8 & $\begin{array}{l}\text { Solution Collapse Breccias, sec- } \\
\text { ondary porosity } 20 \% \text {, dolomite } \\
40 \% \text {, micrite and sparite } 40 \% \text {. }\end{array}$ & $\begin{array}{l}\text { 23: Gypsum, anhydrite } \\
\text { and dolomite irregularly } \\
\text { laminated. }\end{array}$ & $\begin{array}{l}\text { 9: Evaporites on } \\
\text { sabkhas } \\
\text { Salinas. }\end{array}$ & $\begin{array}{l}\text { Vugy and } \\
\text { fragmented }\end{array}$ \\
\hline 9 & $\begin{array}{l}\text { Solution Collapse Breccias calci- } \\
\text { fied evaporitic crystâis. }\end{array}$ & $\begin{array}{l}\text { 23: Gypsum, anhydrite } \\
\text { and dolomite irregularly } \\
\text { laminated. }\end{array}$ & $\begin{array}{l}\text { 9: Evaporites on } \\
\text { sabkhas } \\
\text { Salinas. }\end{array}$ & $\begin{array}{l}\text { Vugy and } \\
\text { fragmented }\end{array}$ \\
\hline 10 & $\begin{array}{l}\text { Solution Collapse Breccias, } \\
\text { evaporitic rosette and lenses } \\
\text { within mudstone, secondary poros- } \\
\text { ity } 25-30 \% \text {. }\end{array}$ & $\begin{array}{l}\text { 24: Dolomite and Dolo- } \\
\text { mitic limestones with } \\
\text { evaporitic crystals. }\end{array}$ & $\begin{array}{l}\text { 8: Restricted cir- } \\
\text { culation shelf } \\
\text { and tidal flats. }\end{array}$ & $\begin{array}{l}\text { Vugy and } \\
\text { fragmented }\end{array}$ \\
\hline
\end{tabular}




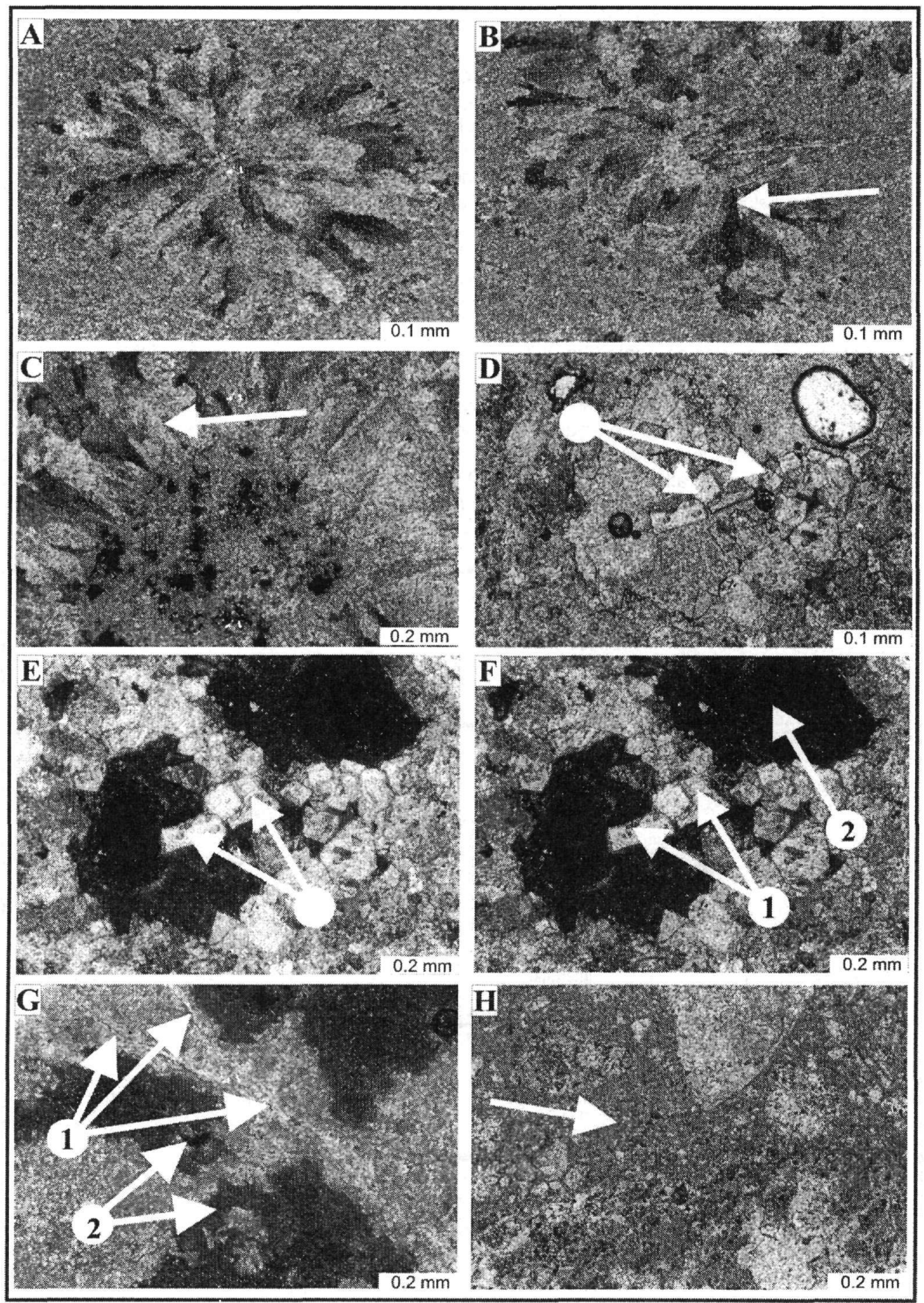

Figure 3. (A) Evaporitic rosette, cross polars, (B) Radiaxial or fibrous pore filling cement, cross polars, (C) Radiaxial cement, (D) Dolomitic rhombs, (E) Dolomitic rhombs, (F) 1: Dolomitic rhombs 2: Vugs, cross polars, (G) 1: Desiccation cracks 2: Vugs, (H) Red Brown cement showing diagenesis during subaerial exposure. 


\subsection{Facies interpretation and diagenesis}

Anhydrite occurs always as a relic mineral replaced initially by gypsum and calcite during diagenesis. Gypsum and anhydrite are considered as both depositional and diagenetic, due to instability and deformation through crystal growth, intake of water of crystallization or compaction. The interpretation of dolomite evidence stratigraphically controlled genesis, during early diagenesis of carbonate. Later, duriing diagenesis dolomite is dissolved or replaced by low Mg-calcite. The dissolution seems to be further enhanced by the increased secondary porosity created during dolomitization. The calcite transformation to dolomite causes an almost $10 \%$ decrease in volume.

A five-stage sedimentological and diagenetical evolution, for Triassic rocks, can be distinguished. In the first stage, a thin layer of lime mudstone is deposited (Fig. 4A). In the second stage, the salinity increases slightly and evaporitic minerals are precipitated (Fig. 4B). In the third stage, due to evaporation, the solution becomes hyper saline and result to the evaporitization of the lime mudstone (Fig. $4 \mathrm{C}$ ). In the fourth stage, the $\mathrm{Mg} / \mathrm{Ca}$ ratio of the solution increases and the dolomitization of the lime mudstone begin (Fig. 4D). In the fifth stage, as a consequence of the influx of low $\mathrm{Mg} / \mathrm{Ca}$ solution of metecric origin the dolomite is replaced from low Mg calcite (Fig. 4E). The processes were repeated sequentially and synchronously probably because of short-term sea-level fluctuation. Every time where the sediments were short term subaerialy exposed, desiccation cracks were created. The depositional environment was intertidal to supratidal and according to Facies Zones (FZ) classification after Flugel (1972) and Wilson (1975), corresponds to restricted circulation shelf and tidal flats (FZ 8) and sabkhas - salinas (FZ 9) with evidence of extensive sub aerial exposure (Tab. 1). The same environment has been proposed by Pomoni-Papaioannou (1985).

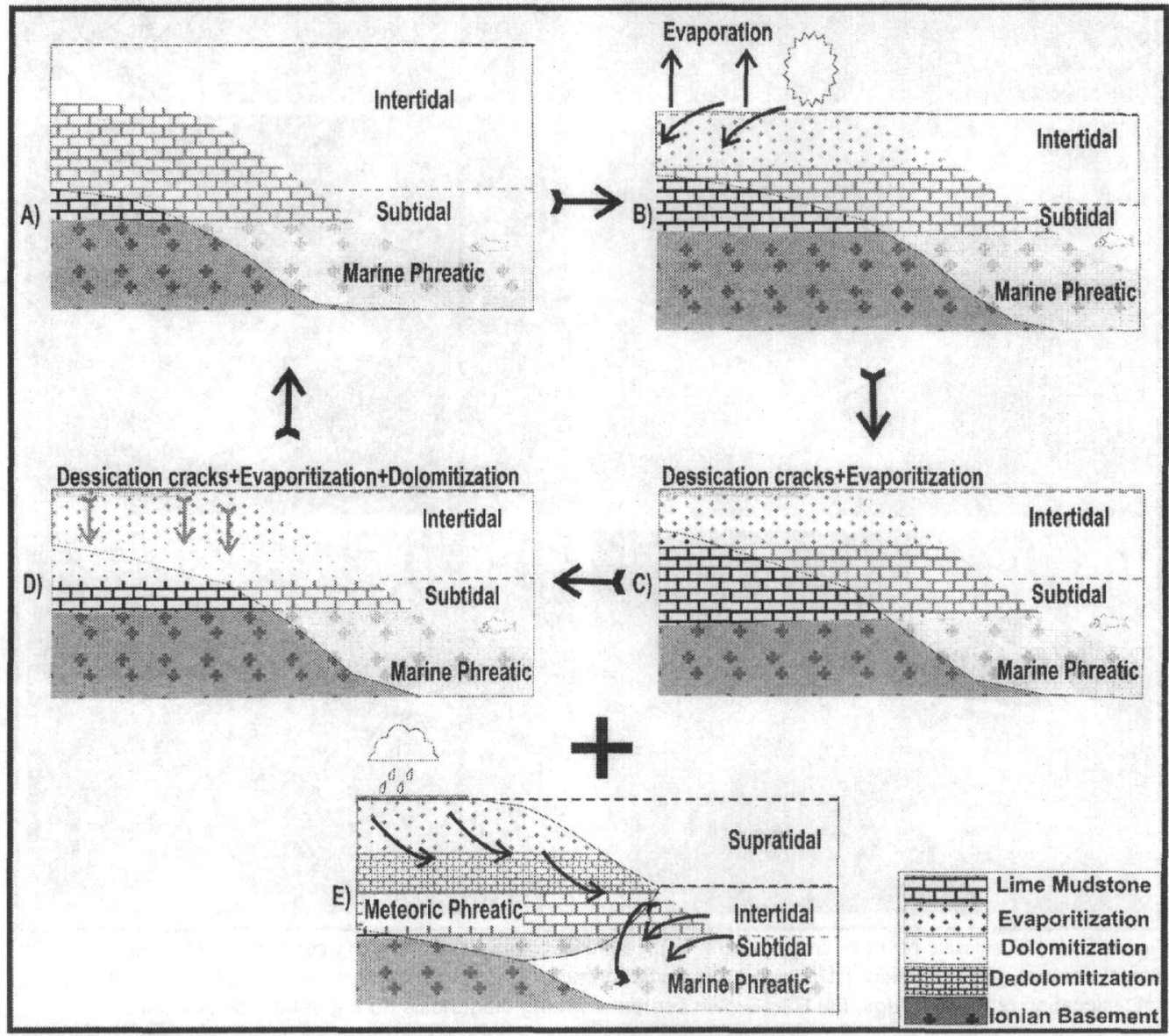

Figure 4. Sedimentation and diagenesis processes. See text for more details. 
In order to establish a palaeogeographic and palaeoclimatic model for the studied basin during Triassic and as already mentioned before two similar examples, one from Late Miocene Mediterranean basin and one from now days Christmas islands lagoonal lakes are presented briefly.

\subsection{Late Miocene palaeogeography and palaeoclimatology of the Mediterranean basin}

During Miocene in the Mediterranea aridity and humidity have been recorded in the sediments. During arid conditions the deposition of halite prevailed in the Mediterranea and during humid conditions gypsum/anhydrite, gypsarenites and very fine clastics were deposited. The two successions are known as Lower and Upper evaporites. The duality is explained by the establishment of the ever evolving desert/monsoon system with seasonal and longer term cyclical changes emphasizing the duality (Griffin 2002).

Monsoons are mainly expressed in tropical and intertropical areas where there is a seasonal wind change with one season bringing moisture and the other aridity. The focus of the monsoon is the Intertropical Convergence Zone (ITCZ) where the easterlies or Trade winds from each hemisphere converge and abundant moisture is released. The ITCZ annually migrates northwards in phase with the development of northern summer and southwards in the winter (Griffin 2002).

The African/Asian Monsoon is intensified by the average insolation. When a critical insolation threshold is reached then the onset of the monsoon is abrupt (Kutzbach \& Liu 1997; DeMenocal et al. 2000). The changes in insolation come from the precession of the equinoxes, which modifies the intensity of solar energy and the period of energy absorption by sea and land surface. As a consequence the African/Asian Monsoon seems to have two phases on the precessional $21 \mathrm{ka} \mathrm{cycle.} \mathrm{The}$ one transferred moisture to Southern Asia and the other to North Africa.

\subsection{Christmas islands lagoonal lakes}

In Christmas islands lagoonal lakes in the Central Pacific the sedimentary record is consisted of three main lithologies, organic rich, carbonate rich and evaporitic with a thickness ranging from millimeters to centimeters. The organic rich lithology comes from death and burial of cyanobacterial population during extreme conditions, such as storm events (Trichet et al. 2001). This bears great similarity to clayey organic rich layers of the Ionian zone. It is assumed that during arid conditions halite or gypsum/anhydrite was precipitated, dependent on the evaporation rate and during more humid conditions organis rich and carbonate rich layers were deposited. A striking feature is the high amount of carbonate precipitation versus sulfate (Trichet et al. 2001), which is absent in the intertidal-supratidal environment of the Triassic Ionian Basin.

The area is near the equator $\left(\sim 2^{0} \mathrm{~N}\right)$ within the ITCZ and the duality was explained by the influence of ENSO events (EI Nino Southern Oscillation) with a year recovery period from arid to humid conditions. The Sea Surface Temperature (SST) plays a very important role in the intensification of ENSO and the sea-land temperature gradient as well. In the lonian Zone ENSO events may have played crucial role but further research should be contacted in order to make such a conclusion.

\subsection{Triassic Ionian Basin}

\subsubsection{Palaeogeografy and palaeoclimatology}

Judging from the known outcrops in Western Balkans, the study area was located southern than its present position, in an extended tidal flat with a few tenths to hundreds kilometers width and several hundreds kilometers long. Palaeogeographically the area was located in the Northwestern shoreline of Neotethys (IGCP Project No. 369) (Fig. 5). Taking into account the existing data, regarding evaporites in Greece and in the rest West Balkans, an extended evaporative environment can be imposed. This is likely to be a tidal flat or many adjacent tidal flats with numerous sabkhas. From early to late Triassis, the whole area was within the intertropical and subtropical zone and in some extends in the ITCZ. It is possible the shifting of the ITCZ to be such as the lonian zone falls once within the ITCZ and once within the middle of the Hadley cell the other. As a consequence the evaporation minus precipitation has negative values once and positive values the other. 


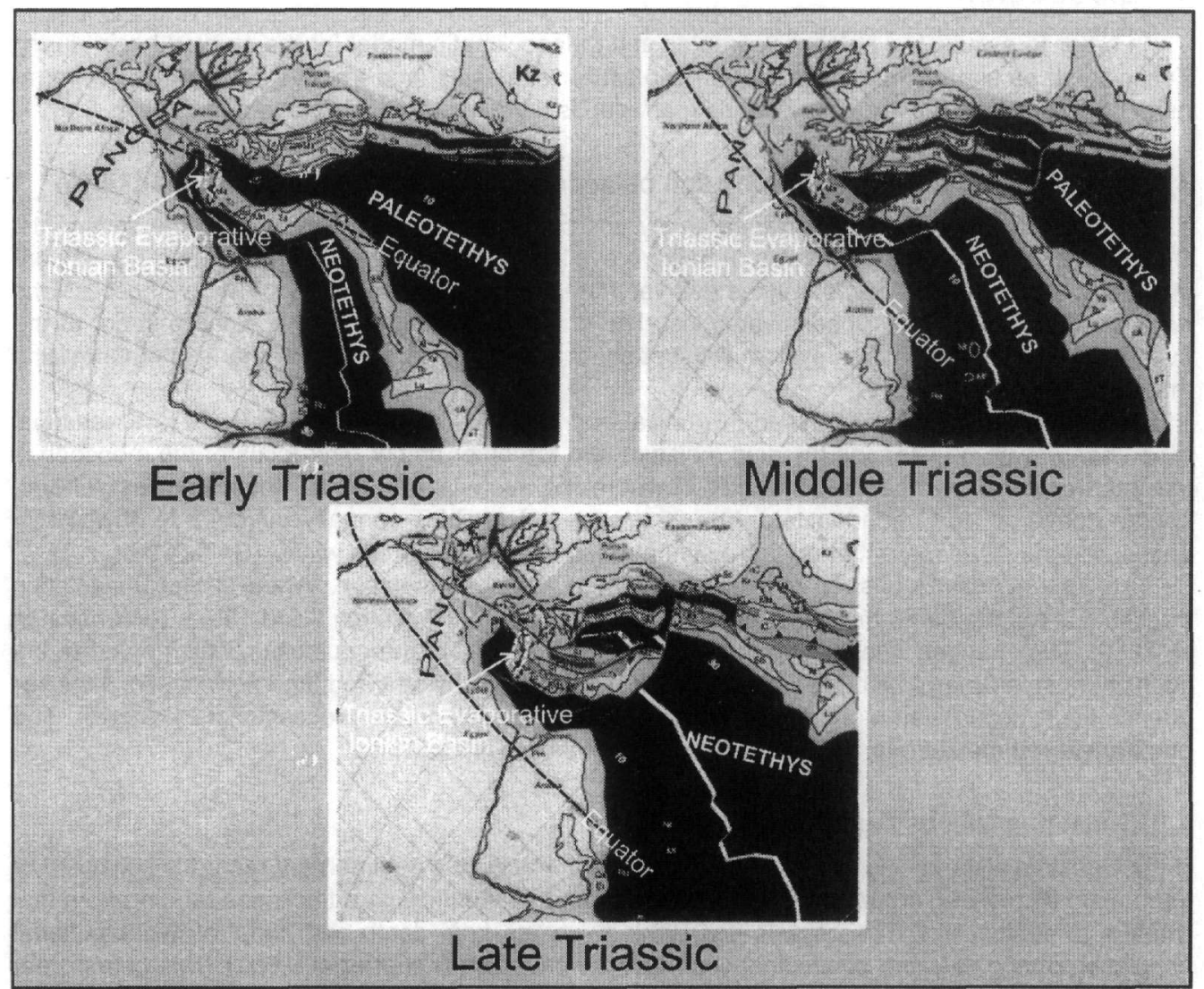

Figure 5. Geographical maps. The arrows show the Evaporitic Triassic Ionian Basin (IGCP Project No. 369).

\subsubsection{Sedimentology and diagenesis}

There are no fragments of the overlying limestones within the studied solution collapse breccias. The Triassic breccias have $200-250 \mathrm{~m}$, maximum thickness in outcrops. Taking into account their solution collapse in origin we have to assume that a significant thickness of carbonates and sulfates were subaerialy exposed for a long period of time. The subaerial exposure should have taken part before the deposition of the overlying limestones, in the Upper Triassic, during a one million year eustatic sea level fall (Haq et. al 1987).

\section{CONCLUSIONS}

The combination of sedimentology and knowledge gained by analogous case studies of geological record, where the suitable climatic models have been applied, led us to propose the most probable climatic model for the Triassic formations of the lonian zone. Data are indicative of a complex climatic setting. During halite/sulphate precipitation in tidal flats the whole studied area was extremely arid. Aridity was followed by humid periods and the halite/sulphate precipitation was replaced by clayey carbonaceous material, possibly algal mats.

The most probable climatic model is the evolving dessert/monsoon system. The deposition of halite took place during pariods when the entire area was dessert. The sulphates are most possible to have been deposited during seasons before monsoons in hot dry conditions. The carbonates and the carbonaceous materials were deposited during humid periods under the influence of the monsoons. 
There is a critical value in the average insolation where the monsoons are intensified and abundant moisture comes into the area or they are ceased and the area becomes dessert.

Neotethys is the most possible source of moisture over the study area during periods of meridional (monsoonal) moisture transfer.

The Triassic rocks were subaerialy exposed before the deposition of the above sedimentological units possibly in the Upper Triassic, during eustatic sea level fall.

\section{REFERENCES}

BP-British Petroleum Company Limited 1971. The geological results of petroleum exploration in Western Greece. Institute Geology and Subsurface Research, 80, 73p.

Berger A. 1977. Support for astronomical theory of climatic change. Nature, 269, 44-45.

Berger A. 1981. The astronomical theory of paleoclimates. In: Berger A. (ed), Climatic variations and variability: facts and theories. Reidel, Dordrecht, The Netherlands, 501-525.

Berger A. 1984. Accuracy and frequency stability of the earth's orbital elements during the Quaternary. In: Berger A., Imbrie J., Hays J., Kukla G., Saltzman B. (eds) Milankovitch and climate. Reidal, Dordrecht, The Netherlands, 3-39.

Berger A. 1987. Long-term variations of caloric insolation resulting from the earth's orbital elements. Quat. Res. 9, $139-167$.

Catalano R., Doglioni C., Merlini S., 2001. On the Mesozoic Ionian Basin. Geophys. J. Int., 144, 49-64.

DeMenocal P., Ortiz J., Guilderson T., Adkins J., Sarnthein M., Baker L., Yarusinsky M., 2000. Abrupt onset and termination of the African Humid Period: rapid climate responses to gradual insolation forcing. Quat. Sci. Rev. 19, 347-361.

Flugel E. (1972). Mikrofazielle Untersuchungen in der Alpinen Trias. Methoden and Probleme. Mitt. Ges. Geol. Bergbaustud, 21, 9-64.

Griffin D. L. 2002. Aridity and humidity: two aspects of the late Miocene climate of North Africa and the Mediterranean. Palaeog. Palaeocl. Palaeoec., 182, 65-91.

Haq B., Hardenbol J., Vail P. 1987. Chronology of Fluctuating Sea Levels Since the Triassic. Sci. 235, 11561167.

Hay W.W., DeConto R.M., Wold C.N., 1997. Climate: Is the past the key to the future? Geol. Rundsch. 86, 471491.

IGCP Project No. 369. Comparative evolution of Peritethyan Rift Basins. Internet site: http://Wwwsst.unil.ch/igcp 369/igcp369 plates.htm.

IGRS-IFP, 1966. Etude gélogique de l'Epire (Gréce nordoccidentale). Ed. Technip, Paris, 306p.

Imbrie J \& Imbrie J.Z. 1980. Modelling the climatic response to orbital variations. Sci. 107, 943-953.

Karakitsios V. \& Pomoni-Papaioannou F. 1998. Sedimentological study of the triassic solution-collapse breccias of the Ionian zone (NW Greece). Carbonates and Evaporites, 13, 207-218.

Kutzbach J. E. \& Liu Z. 1997. Response of the African Monsoon to Orbital Forcing and Ocean Feedbacks in the Middle Holocene. Sci., 278, 440-443.

Pomoni-Papaioannou F. 1980. Genesis-Diagenesis of Triassic Breccia and nodular gypsum of Epirus, IGME, Mineralogical and Petrografical Research, 2.

Pomoni-Papaioannou, F., 1985. The sedimentology and depositional environment of the Triassic dolomitegypsum facies of western Greece. $6^{\text {th }}$ Eur. Reg. Meet. Int. Ass. Sed., 367-368.

Trichet J., Defarge C., Tribble J., Tribble G., Sansone F. 2001. Christmas Island lagoonal lakes, models for the deposition of carbonate-evaporite-organic laminated sediments. Sed. Geol., 140, 177-189.

Velaj T., Davison I., Serjani A., Alsop I. 1999. Thrust tectonics and the Role of Evaporites in the lonian Zone of the Albanides, AAPG Bulletin, 83, 1408-1425.

Wilson J.L. (1975). Carbonate Facies in Geologic History. Berlin-Heidelberg-New York (Springer), 471p. 